\title{
IGNITING FOLKTALES AS CHILDREN'S LEARNING SOURCES IN SENTANI JAYAPURA PAPUA
}

\author{
Wigati Yektiningtyas \\ Universitas Cenderawasih \\ email: wigati_y@yahoo.com
}

\begin{abstract}
Sentani is one of more than two hundred tribes in Papua that has various folklores as their invaluable cultural heritages. One of them is the folktale. Folktales that used to be passed down with some purposes are not recognised by the people anymore. This serious phenomenon cannot be ignored since there are philosophy, mythology, and indigenous knowledge they carryalong that can be used to build identity and the whole social life of Sentani people. This writing is aimed at igniting Sentani folktales and using them as learning sources for children. Data were collected through observation, deep interview, and recordings in three areas of Sentani, namely East, Central, and West Sentani. The study used a socio-cultural approach and involved tribal chiefs, elderly people, parents, and teachers as informants. The study found that folktales are still recognised in remote areas of Sentani, known by some tribal chiefs and elderly people and told mostly in Indonesian. Folktales collected can be used as various learning sources for children, i.e. (1) Sentani language, (2) literacy, (3) indigenous knowledge, and (4) character building. Igniting folktales as learning sources also means doing preservation of Sentani cultural heritages. Initiatives and discussion with tribal chiefs, government, and educators are urgently needed.
\end{abstract}

Keywords: Sentani, cultural heritages, folktales

\section{MENGHIDUPKAN KEMBALI CERITA RAKYAT SEBAGAI SUMBER BELAJAR ANAK-ANAK DI SENTANI JAYAPURA PAPUA}

\begin{abstract}
Abstrak
Sentani adalah satu dari ratusan suku di Papua yang memunyai berbagai pusaka budaya yang tidak ternilai harganya. Salah satunya adalah cerita rakyat. Cerita rakyat yang dahulu dituturkan dengan bermacam tujuan ini kini telah ditinggalkan oleh sebagian besar masyarakat. Fenomena seperti ini tidak dapat dibiarkan karena dalam cerita rakyat terdapat filosofi, mitologi, pengetahuan, dan nilai kearifan masyarakat yang dapat digunakan untuk membangun identitas dan kehidupan masyarakat secara keseluruhan. Artikel ini bertujuan untuk menghidupkan kembali cerita rakyat dan menggunakannya sebagai sumber pembelajaran untuk anak-anak. Data dikumpulkan melalui observasi, wawancara mendalam, dan rekaman di tiga wilayah Sentani, yaitu Sentani Timur, Sentani Tengah dan Sentani Barat. Penelitian menggunakan pendekatan sosial-budaya dan melibatkan pemangku adat, tokoh masyarakat, orang tua dan guru sebagai informan. Penelitian ini menemukan bahwa cerita rakyat masih dikenali di wilayah terpencil Sentani, dikuasai oleh sebagian kecil pemangku adat
\end{abstract}


dan tokoh masyarakat, dan dituturkan sebagian besar dalam Bahasa Indonesia. Cerita yang diperoleh dapat digunakan sebagai sumber pembelajaran bagi anakanak, yaitu (1) bahasa Sentani, (2) literasi, (3) kearifan lokal, dan (4) pengembangan karakter. Menghidupkan kembali cerita rakyat sebagai sumber pembelajaran berarti melakukan preservasi pusaka budaya masyarakat. Inisiatif dan diskusi dengan para pemangku adat, pemerintah dan pemangku pendidikan perlu segera dilakukan.

Kata kunci: Sentani, pusaka budaya, cerita rakyat

\section{INTRODUCTION}

Sentani people live in the edge and in the islands of Sentani Lake, Jayapura, Papua. They speak Sentani language with three dialects: Eastern, Central, and Western Dialects. Administratively they live in two regencies. East Sentani belongs to Jayapura Municipality while Central and Western Sentani belong to Jayapura Regency. Besides the beauty of the nature, Sentani people have various cultural heritages that flourished in the past. Some of them are oral poems (helaehili, ehabla, helaehuba), folksongs, folktales (myths, legends, and fables), traditional expression, dances, paintings (malo), carving (ohomo), and traditional architecture (John Ibo, 65 years, April 2017). Oral poems were heard where there were deaths, social gatherings, and traditional ceremonies; dances were usedasexpression of happiness; paintings and carving were conspicuously seen in their costumes, houses, canoes, pedals; folktales were passed down to children and grandchildren for various purposes; and traditional expressions were used in their communication.

Unfortunately, based on the observation in recent 30 years, and supported with interviews in December 2017with Origenes Monim (50 years) as the principal of Sekolah Adat Jayapura (Jayapura Customary School), and
Sam Suebu (60 years) an elder, those heritages cannot be easily found. There are various reasons as the background: factors of imigrants, modernization/ technology, and mixed marriages. Compared to other people who live in the highland and small towns, Sentani people that live in Jayapura as the capital of Papua Province had experienced contact with people from other places in Indonesia who flooded Jayapura every year, like people from Jawa, North Sumatra, South Sulawasi, North Sulawesi, East Nusa Tenggara, Mollucas, etc. Those people with their different culture, local languages and habbits, directly and indirectly influence Sentani people's life.

They tend to use Indonesian as their daily communication, even with their family. They do not speak Sentani language anymore. Consequently, it is hard for most of Sentani people to follow and learn folklore that are passed down in Sentani language. Mixed marriages also contribute similar phenomena. Since the parents come from different culture, they tend to be more eclectic: leaving Sentani culture and acknowledge thechildren to modern culture. Modernization/ technology made people to be more individualistic and independent. They can easily use telephone to contact their 
relatives. Social gatherings are scarcely held. They do not have opportunities to maintain their culture by practicing through direct communication and in social gatherings. Unfortunately, some tribal chiefs did not do significant things to make the culture alive again.

One of Sentani heritages that is not recognised by most people is folktales. Folktales (myths, legends, and fables) that used to be passed down with various purposes are left behind by the people. This phenomenon cannot be ignored since folktales bring philosophy, mythology, indigenous knowledge and values that portray Sentani life. This is in line with Polley (1978) who said "... folklore is important not only because it brings entertainment but also because it sheds light on people's worldview,personality traits as well as their values and main concerns in life". According to Ramses Ohee (88 years), an ondofolo (big tribal chief) said that in the past parents always used folktales to educate their children. They taught socio-cultural values, i.e. hardwork, discipline, coorperation, honesty, love, respect, truth by telling them myths, legends, and fables. Indigenous knowledge like how to build houses, make canoes, do gardening and fishing, were taught by using folktales too. As an example, there are some famous brave hunters known by some people until now, i.e. Ebeit and Hayae by reading or listening to some legends or myths. If those folktales are not recognised by the people anymore, folktales will be extinct together with the socio-cultural values they carry with. If it happens, Sentani people do not only lose their identity but they will also lose their whole life.
This research is an initiative to ignite folktales as learning sources for children. Sentani children are prioritized since they are the future generation of Sentani who will bring along their ancestor's cultural heritages in their life and pass them down to the following generation. Simply, this writing aims at exploring the existence of Sentani folktales and revealing thosesubstances as learning sources for children.

\section{METHOD}

This writing is a part of the big research conducted by the researcher as the research leader in 2017-2018. The research entitled "Preservation of Sentani Language for Children by Using Sentani Folktales, Jayapura Regency, Papua" was financially supported by the Ministry of Research, Technology and Higher Education and the Institute for Education Development in Remote Areas of Papua. The research was conducted in the remote islands in Lake Sentani as well as the lake beach. The population spread in three major areas, namely the East Sentani, the Central Sentani, and the West Sentani. They speak in three different dialects based on the areas they live: Eastern, Central, and Western Sentani dialects (Deda, 2018). It is noteworthy that the different dialects were not taken into account in this study since the different linguistic structures did not substantially change the meaning significantly. Some vocabularies may be different but they still understand each other.

This is a qualitative research. By applying socio-cultural and ethno linguistic approach, the data gathered in the study comprised of two kinds, i.e. primary and secondary data. 
The primary data were the folktales gathered from the informants, namely tribal chiefs (ondofolo/khote), the elderly people of Sentani, and parents wholived in East Sentani (Waena, Asei Island, and Ayapo), Central Sentani (Hobong, Sentani Kota), and West Sentani (Kwadeware and Doyo Lama). From the folktales gathered, they were then selected to have some representative folktales for the children. Rewriting those folktales in simpler Sentani language was done. The substances were also selected. The tales should provide socio-cultural background, motivate children to follow good values of the tales, and free from violence (Bunanta, 2012). Crippen (2012) also highlighted the importance of social values and cultural heritages in choosing literarture for children. The representative folktales were then analyzed to reveal various substances to be utilized as the learning sources. The primary data were holistically supported by a series of observation, interviews, recordings and long active participation of the researcher. The secondary data were obtained from the written documents of previous research on culture, language, and folk life of the Sentani people.The rewritten folktales were then used as the teaching materials

for students of Early Childhood Education (PAUD Hadassah and PAUD Sejahtera), Kinder Garten (Sekolah Adat Hobong), and Primary School (SD YPK Yokabaru and SD YPK Asei Pulau) for about 4 months (January-April 2018).

\section{RESULTS AND DISCUSSION Result}

From the research there revealed two main things. Firstly, folktales in Sentani still exist and recognized by limited people. From the observation and interview, only limited tribal chiefs (ondofolo and khote), elderly people and parents in East, Central, and Westen Sentani were able to tell folktales. Some told the folktales in Sentani language and some told the folktales in mixed languages, Sentani and Indonesian. The Tables 1, 2, and 3 below explain the facts.

Secondly, from the folktales that were tried out in Early Childhood

Table 1. List of Folktales Tellers in East Sentani

\begin{tabular}{clccc}
\hline No. & Tellers & Amount & Language Used & Notes \\
\hline 1. & Ondofolo & 3 & Sentani & fluent \\
2. & Khote & 2 & Sentani & fluent \\
3. & Elderly people & 5 & Sentani and Indonesian & hesitated \\
4. & Parents & 4 & Sentani and Indonesia & hesitated \\
\hline
\end{tabular}

Table 2. List of Folktales Telles in Central Sentani

\begin{tabular}{clccc}
\hline No. & Tellers & Amount & Language Used & Notes \\
\hline 1. & Ondofolo & 5 & Sentani & fluent \\
2. & Khote & 4 & Sentani & fluent \\
3. & Elderly people & 9 & Sentani and Indonesian & fluent \\
4. & Parents & 12 & Sentani and Indonesia & hesitated \\
\hline
\end{tabular}


Table 3. List of Folktales Telles in Western Sentani

\begin{tabular}{clccc}
\hline No. & Tellers & Amount & Language Used & Notes \\
\hline 1. & Ondofolo & 2 & Sentani & fluent \\
2. & Khote & 2 & Sentani & fluent \\
3. & Elderly people & 3 & Sentani and Indonesian & hesitated \\
4. & Parents & 4 & Sentani and Indonesian & hesitated \\
\hline
\end{tabular}

Education, Kinder Garten, and Primary schools, it was found that folktales functioned as learning sources for children, i.e.(1) Sentani language, (2) literacy and numeracy, (3) indigenous knowledge, and (4) character building.

\section{Discussion}

\section{The Existence of Sentani Folktales}

Even though limited circulated and told by limited people, Sentani folktales still exist now. Danandjaja (2002) categorized folktales into myth, legend, and fable. Phenomena in Sentani show that names of villages, islands, mountains, lakes, rivers, forest, plants, animals, and some specific things are related to legends, myths, and fables. For examples, the origins of islands in the Sentani Lake are related to a giant snake that sank when it brought Sentani people moved from East Sepik, PNG to Asei Island. Name of Abepura town is related to the quarrel of two brothers about their destination. A fatal mistake done by a tribal chief destroyed Nelebu Village (Yektiningtyas and Monika, 2017). In the past, grandparents and parents (usually grand mother and mother) told tales in Sentani language to their children/grandchildren in their spare time during their break in gardening or fishing. An informant (Lunia Nere, 87 years) also said that tales were also told as bed time stories. Values revealed in the tales were used to educate their children/grandchildren morally, spiritually, and socially. They taught the children/grandchildren to be hardworking, discipline, responsible, polite, honest, and respectful ones.

Commonly Sentani folktales are classified into five categories, namely (1) taboo - tales circulated among big tribal chiefs (hu ondofolo), (2) specific tales - circulated among tribal chiefs (khote), (3) exclusive adult tales circulated among specific tribes for both males and females, (4) inclusive tales - circulated among adults, males and females even those who come from different groups, (5) children tales - told specifically for children (Yektiningtyas and Monika, 2017, see also Dundes, 1984). Ramses Ohee (88 years) added that those classifications are strictly maintained, even up to now. Children are forbidden to hear or eardrop the adult tales. Common people are not allowed to hear/eardrop taboo tales. Violation results pelo (curse) i.e. sickness or even death.

Interestingly, nowadays even though not circulated well, folktales are still used as references of some tribal chiefs (ondofolo/khote) to teach people about coorperation, respect, discipline, and hardwork. From the research it was depicted that in East Sentani there were only two ondofoloof five existing ones, twokhote of ten existing ones who were able to tell tales in Sentani 
language fluently, nineelderly people and twelve parents were able to tell folktales in mixed languages. In Central Sentani, there were five ondofolo from seven existing ones, five khote from ten existing ones who were able to tell tales in Sentani languages fluently, nine elderly people, and twelve parents were able to tell folktales in mixed languages. In Western Sentani, there were two ondofolo offive existing ones, twokhote of five existing ones who were able to tell tales in Sentani language fluently, three elderly people and four parents were able to tell folktales in mixed languages. Based on the observation, elderly people and parents tended to shorten the folktales or skipped some information in the tales because they forgot the original ones. Their ability in telling tales was not automatically related to their Sentani language. It was also influenced by their attention to the cultural heritages. They used Indonesian language in telling the tales and inserted some Sentani words especially for various terminologies that could not be directly translated to Indonesian. An ondofolo said that he was afraid those tribal chiefs', elderly people's, and parents' poor Sentani language and "ignorance" for the cultural heritages would influence young generation's appreciation for their heritages, Seeing those facts, revitalizing and disseminating Sentani folktales in creative and innovative ways, especially for children are needed.

\section{Sentani Folktales as Learning Sources for Children \\ Source for Learning Sentani Language}

In 1996 when Hartzler conducted the research on the phonology of
Sentani language, Sentani speakers were about 25.000 people. According to a long observation (1998-now) and strengthened by some informants ( $R$. Ohee, 88 years, Fredrick Sokoy, 55 year) the speakers have decreased from time to time and children do not speak Sentani language anymore. A Sentani linguist, Andreas Deda (2018) figured out that only some children in remote islands of Lake Sentani speak the language passively. As future generation who are supposed to be responsible for the life of Sentani cultural heritages, they have to be saved. It needs an initiative to help Sentani children to learn their local language. From the emphirical experience, folktales were one of alternative materials to be used as a language learning source. Children learned Sentani language through folktales without burden. Besides having emotional ties with the folktales, they could also learn their ancestors' sociocultural heritages. Hastuti, Reza, and Teddy (2014) underlined that language learning through folklore is very possible as a medium of education that provide entertainment and national cultural heritage and supports the achievement of communty's ability to speak language skills. Similarly, Lwin (2016) also pointed out that folktales were beneficial to teach languages (see also Lazar's arguments that the authentical form of literature can be used as interesting media to teach language). The newest research in 2017 (Yektiningtyas and Monika), found that Sentani children faced difficulties in learning their local language. The problems were triggered by (1) the parents do not speak it at home, (2) pronunciation, (3) sentence structure, 
(4) tenses, (5) adposition, and (6) counting system.

Following is the example a folktale that can be used as a material to learn Sentani language (taken from "The Cassowary and the Sparrow").

Phere ayae manggung mbai. Nawali puyakha akhlane nekewole, Papua. Naoro khokho lekeisele. Nau hekhi kabani. Nanoro khabani lekeisele. Nama foisele. Neyae uhilae-hilae khai. Neyae ayae fele-felere $u$ hilaehilaeyae ikae womi. Ayae fele-fele pukhae waliye ikowate. Manggung re autaei re inyainyelere. A nembanye elaikokhae manggung re hambungbate nyanyelere. Hineyae ende inyendere? Nanemenne feyae waliyae kowate. Bokikiyae elelae riyae nahului. Ayae ehi pumara ohaikokhae. Hornohane hirewonge bokiki manggung na jokho femmae rorokokhae. Manggung rukhae hirewole. Rukhe nanoro insekokhe. Pelehera manggung wekite nahului bham. Neyae ayae fele-felere hamang eyaroi. Ayae fele-fele onomi nekewate akhlane

(A long time ago there lived a cassowary. He lived in the Sentani jungle, Papua. His body was big and tall. His legs were long and strong. His wings were big and strong. His feathers were beautiful. But he was naughty. He always bothered other little birds in the jungle. The little birds were not happy. They wanted to give him a lesson. They decided to give him a magic necklace. But who would give it to him? Eveyone was scared. Surprisingly, a little sparrow said that he would do it. Other birds were amazed. Then, while the sparrow hung the necklace, he was pecking the cassowary's eyes. Cassowary was painful. He fell and his wings were broken. Cassowary could not fly since then. He could not carry little birds' food away anymore. Finally, the little birds lived peacefully in the jungle.)

Different from Indonesian alphabet that has 5 vowels and 19 consonants, Sentani language has 7 vowels and 10 consonants. Sentani has seven vowels and variants, namely vowel / i / with two variants [i ] and [ I ], vowel / e / with two variants $[\varepsilon]$ and $[\mathrm{e}]$, vowel / æ/, vowel / a /, vowel / ə /, vowel $/ \mathrm{u} /$ with two variants [ $\mathrm{u}]$ and [ $\mathrm{U}$ ], and vowel / o /. Sentani has ten consonants, namely consonant / p / with three variants [ ph ], [b], and [ß], consonant / $\mathrm{t} / \mathrm{with}$ three variants [ th ], [ d ], and [ $\breve{r}$ ], consonant / $\mathrm{k} /$ with four variants [ $\mathrm{kh}],[\vartheta],(\mathrm{dog}),[\mathrm{g}]$, and [ '] (glotal), consonant / h / with two variants [ $\mathrm{s}]$ and $[\mathrm{h}$ ], consonant /f /, consonant / $\mathrm{n} / \mathrm{with}$ four variants [ $\mathrm{g}]$, [ yw ], [ $\tilde{\mathrm{n}}]$, and [ $\mathrm{n}$ ], consonant / $\mathrm{m} /$, consonant / 1/, consonant / y / with two variants $[\mathrm{dz}]$ and $[\mathrm{y}]$, and consonant /w / (Hartzler, 1996).

Those different vowels and consonants from Indonesian make them hard to pronounce some sounds like $[\varepsilon], / æ /,[\mathrm{I}],[\varepsilon]$, and $[\mathrm{U}]$ and also some consonants like [ph ], [ $ß]$ ], th ], $[\varnothing],[\mathrm{kh}],[\vartheta]$, and $[\mathrm{dz}]$ that they are not used to. The folktales above can be used to practice vowel $[\varepsilon]$ in "nyanyelere", "hineyae", "inyendere", "nanemenne" and "kowate"; vowel /æ/ in "neyae", "uhilae-hilae", and "femmae"; vowel / a / in "fele-fele", "foisele"; consonant /kh/ in "pukhae", "puyakha" and 
"akhla". Those practices and intensive drills are needed to avoid mistakes and misunderstanding since some Sentani words sounds similar but different in meaning, for example,"yoku" (dog) and "yokhu" (name of tribe), "khobu" (stupid) and "khoßu" (coconut water).

From the tale, children can also learn some vocabularies like khaban (big), kending (small), foi (good), uhilaehilae (naughty) or body parts like oro (leg), noro (wing), hekhi (body), ma (feather). They can learn short phrases like hekhi lekhe (big body) and oro khokho (strong leg). Possesive form in short sentences can be learnt as well like "his body is tall and strong" (nau hekhi kabani), "his leg is long and strong" (naoro khokho lekei sele) and "his wings are big and strong" (nanoro khabani lekeisele). A longer sentence in "bokiki manggung na jokho femmae rorokokhae" (the sparrow pecked cassowary's eyes) can be introduced as well. Children who are accustomed with preposition are confused with postposition in Sentani language. A sentence "Hineyae ende inyendere?" (who will give it to him?) is a good example to learn postposition. "Re" in "inyendere" means "to".From those examples taken from the tales, teachers can develop their materials by giving other examples from daily life conversation.

\section{Source for Literacy and Numeracy}

Compared to some places in Indonesia, literacy and numeracy rate in Papua, including in Sentani, is very low (National Cencus, 2010). To increase Sentani children's reading habit, interesting and motivating reading materials should be provided. Emphirical experiences have proved that Sentani children prefer reading materials that are not allienated from their life. This is in line with Lazar (2002) who highlighed that emotional ties between the tales and the readers (listeners) are also important factor that encourage children to read. It is easier for them to follow "The Legend of Lake Sentani" rather than "The Legend of Lake Toba" or "The Legend of Rawa Pening" since they are already familiar with their environment like traditional house architecture, paintings (malo), carving (ohomo), tribes, canoe, pedals, flora (walloby, bird of paradise, wild pig), and fauna (sago, eme, raime, ru, ai, kanbai) rather than architecture, paintings, carvings, flora, and fauna from other places. Following is the example:

One day, both the ondofolo's sons, named Wali and Haphoye went to the Cyclop's mountain to look for the source of the swishing swishing. After they arrived at the top of the mountain, they found a hut. Wali asked his younger brother to hide, and then he went to the hut to know who lived there. He found out that the dwellers of the hut were an old married couple. ("Legend of Sentani Lake").

The above folktale is familiar for the children since they know the term "ondofolo" (the big tribal chief) who has social influence in their daily life, they are also accustomed with traditional name like Wali and Hapoyae. They live around Cyclop Mountain as well. They do not only see the mountain every day and its flora and fauna but they also "feel" and experience them. Those emotional ties that motivate and 
encourage them to read (or to listen) the folktales can be used as a stepping stone to enhance vocabulary mastery and build their reading habit. It was also highlighted by Masoni (2018) that folktales are invaluable window to improve vocabularies. Based on the emphirical exeperience, children were happy reading "their own tales", having good reading comprehension, retelling those tales to their friends, and asking them to read the same tales.

Counting system in Sentani language is complicated for children. It is not only because the parents never use it at home but also because Sentani counting uses specific rules. Using five bases numbers, Sentani language uses fingers, hands, toes, and body to count. The word "mbai" (one) in the first line of the tale above can be used as a starting point to teach numbers. From this tale, the teachers can develop it and teaches number 2 to 10 , i.e. bhe (two), name (three), keli (four), mehembai (one hand) (five), me hinimmbai (one hand plus one finger) (six), me hinim bhe (one hand plus two fingers) (seven), me hinim name (one hand plus three fingers) (eight), me hinim keli (one hand plus four fingers) (nine), me bhe (two hands) (ten). Using songs to help the children in memorizing numbers, i.e. one to ten will be a great help fo them as well.

\section{Source for Indigeneous Knowledge}

One of folktale functions is teaching indigineous knowledge for its listeners or readers (Chiparausha \& Frereick, 2018; Rahayu, 2010). Unfortunately, since folktales as cultural heritages that bring important social and moral values are not acknowledged by young generation anymore, especially children, this writing attempts to explore Sentani folktales and (re)introduce indigenous knowledge implied in the tales, i.e. hunting, fishing, gardening, making house, making canoes, painting, and carving. Those teachings are important considering the fact that old Sentani people were wise in conserving nature. They never exploited the land, the lake, and the mountain just for shelters and food. It contradicts with young people in Sentani now who tend to exploit nature for their physical needs (Yektiningtyas and Monika, 2017). This leads to natural disasters. One of the evidences is big flood happened in Sentani in March 2019 that destroyed the land, the junggle, the lake, the mountains and killed hundreds people.

There are some kinds, rules, and rituals in hunting, fishing, gardening, and even in making houses and canoes that are not recognized by children in Sentani. There are also some local wisdom implied in those process. In hunting, for example, there were some rules that was stricltly obeyed by Sentani people, i.e. hunting was done in group, only males went hunting, females were not allowed to touch hunting tools, males had to be clean physically and spiritually before hunting, hunters had to express special spell. Violence against the rules resulted pelo (curse), i.e. either accident (sikness) or death.

There were some kinds of fishing systems done exclusively by women and men. Women did kahela (done in group of 10 using net), heula (done in group of 6 using smaller net), wafolo (diving, done in a group), pei (catching fish on the beach), andui (done individually using wau, sticked fish net), tanserau (like andui but done by two women), meboiboi 
(catching fish using bare hands), and eru (trapping fish in a canoe). Men caught fish by using blowpipe, onggei (spear), and fishing hook (kaige). Those kinds of fishing systems and hunting process are not recognized by children anymore. Fortunately some folktales revealed those important knowledge and they can be utilized as learning media.

Another example is gardening system in which Sentani people also have a strict labor division. Men in group selected and prepared the land and made garden fence, while women did planting, cleaning and harvesting. "Ebi and Kandei" shows how Sentani people selected the right land to garden and did gardening in the past.

After they arrived, both of them got down the canoe and inspected the land. Then Kandei asked Ebi, "What do you think about this place? This land is fertile. You see, there is river over there!". Both of them then agreed to do gardening. They worked hard cleaning the land. They then planted the seeds. While the waited for the harvest time, they also cleaned the garden from the weeds".

The word "the right land" refers to Sentani mythology that gardening might not destroy nature. Sentani people never burnt the land that will damage the topsoil. They never cut the big trees down. Keeping their beleif that big trees are the god/godess' homes had avoided old Sentani people from natural disasters like flood, land slide, and bush fire.

Besides giving knowledge that can be explored to be introduced to young generation, those folktales also portray local wisdom. Exploring local wisdom revealed in folklore in language teaching, as it was depicted by Prasetyo (2016) can be used as an ideal medium to conserve Indonesian cultural heritages as well. Children can learn that in their simple life, their ancestors had knowledge and strategies in facing possible difficulties of life. Various fishing systems show their strategy in meeting their life's needs just in case there were natural disasters like storms, heavy rain, and bad weather. In hunting, gardening, making house, making canoes, the ancestors did rituals. They realized that as weak people they needed Supreme Being to help them in finishing their reponsibilities. Labor division between male and female in gardening teaches about the ballance of taking responsibility in life. From folktales that tell about making houses and canoes, children can learn to choose the correct wood to make houses, canoes, and pedals. They can also learn the right weather to go fishing and the suitable land to do gardening. Children in this modern era who are supported by techonology can do reflection. They are not asked to retreat but they are asked to learn their ancestors' strategy, initiative and make use of them so they are not easily influenced by modernity and easily imitate others' technology. They are motivated to be proud of their identity and encouraged to do better than what their ancestors had done.

\section{Source for Character Building}

It cannot be denied that most Sentani children lose their identity: they cannot speak their local language and do not recognize their culltural heritages They are like standing in intersection and 
do not know where they are heading to (Ramses Ohee and John Ibo, 2017). The Ministry of National Education (Kementrian Pendidikan Nasional, 2011) formulates 18 values of character building. But at least there are five values prioritized for children, i.e. nationalism, integrity, independence, coorperation, and being religious. Those five values actually can be spelled out into detailed values. For example, independence is related to self confidence and self relience, coorperation is related to hard work and discipline, while being religious is related to values of love, respect, honesty, and forgiveness.

Character building values in Papua formally are integrated in some subjects like religion and civics. Based on the emphirical experience and interview with some teachers of Early Childhood Education, Kinder Garten and Primary Schools, values of character building has been taken from the Holy Bible, heroes and heroins stories, and literary works or folktales from places outside Papua. The result of the research has shown that there are various Sentani folktales that depict interesting socio-cultural values that can be used to introduce character education to children. The significances of folktales as media of character building are also underlined by Arief, Sarwiji, \& Slamet, 2017; Kristanto, 2014; Normawati, 2014; andRatna, 2014. In Sentani society, emphirically, besides formal education, socio-cultural values as media of character building can be introduced in family, church/Sunday School, Sekolah Adat (Customary School), and social communities.

Following are some examples of folktales that bring good socio-cultural values for children to learn. From "The Cassowary and the Sparrow", children canlearnaboutfriendship, coorperation, and self confidence. The little sparrow was confident in facing the big greedy cassowary because he was supported by his friends. Friendship is an important value in Sentani. In "Ebi and Kandei", knowing Kandei was angry at Ebi since Ebi pecked his eyes, other birds still asked them to be friends again.

Khandei weungae, 'enfeu ine hanendokhae anende niyeae helem sele roke anekokhae riyeae name hele rokale anekokhale. Belene na jokho nare rorokokhale'.

Yese weumi, "Khandei, weyea bele umekhai wanem ekheleije.

Ebi, weyeae fiye, hamang mali okhoije. Mana mebu foi mokhobo.

Khandei answered, "we burnt banana. He ate too much.

I got only a few. Then I stabbed him".

Yese then said, "Kandei, you cannot be like that. You cannot hurt your friend".

He continued said, "Ebi, you were wrong too, you were greedy. Let you two got in peace".

Hardwork is highly appreciated by Sentani people. It is clearly portaryed in "Ebeu dan Nangga" which tells Ebeu who worked hard to find some feles (a kind of lake shell). It is also found in "Ebi and Kandei" that tells about how they worked hard in finding fertile land to do gardening. Values of hardwork is important to be taught to children since in modern era, most of Sentani children spend most of time in playing 
with friends and watching TV. Another ondofolo of Sentani (Deda, 201) also expressed this phenomenon. He has been seeking ways out to help children to be more productive.

Repecting others is an important value to be taught. There are some proofs from the tales showing that value of friendship (in "Ebeu and Nangga") and (in "Ebi and Kandei") and also value of family (in "The Origin of Ayapo Village") and (in "The Origin of Abepura") broke because the characters of the tales did not respect to each other. Respect is related to telling truth. In "Ebeu and Nangga", Ebeu cheated just for food. He finished all food and did not give his loyal friend's, Nangga, share. He did not respect his good friend. Finally they separated.

From the discussion, it is seen that fokltales can be utilized as sources of character building for children. From folktales, they are able to learn and respect their ancestors' hardwork, discipline, and coorperation. Children who are accustomed to individualism are encouraged to stay in touch with others and respect them. They are also able to learn how to help and love their friends. Listening or reading folktales in schools, homes, communities and good role models of parents, social leaders and elderly people will motivate and encourage children to learn those socio-cultural values to strengthen their character.

\section{CONCLUSIONS}

Folktales are now limited circulated and told only by some tribal chiefs, elderly people, and parents. Folktales are not recognised by most of Sentani children while folklore bring various socio-cultural values that can be adopted as various sources for children in learning (1) Sentani language, (2) literacy, (3) indigenous knowledge, and (4) character building. It is recommended that folktales can be further disseminated and integrated in some materials in schools and used at home and comunity to teach children indigeneous knowledge and local wisdom. Igniting folktales as learning sources also means doing preservation of Sentani cultural heritages. Initiatives and discussion with tribal chiefs, government, and educators are urgently needed. Presenting folktales in more interesting forms, i.e. illustrated books, big books, and animation are cosidered significant to help the children to read and watch folktales and love their identity as well.

\section{ACKNOWLEDGEMENTS}

This research thanks some informants for their help and information, i.e. Mr. John Ibo, Mrs. Lunia Nere, Mr. Ramses Ohee, Mr. Enos Deda, Mr. Albert Hendambo, Mr. Sam Suebu, Mrs. Maria Pepuho, Mr. Fredrick Sokoy, and Mr. Andreas Deda. Without them the research cannot be finished. A sincere gratitude also goes to Dr. Roseye Tanjung as the Head of LPPM Universitas Cenderawasih, Mrs. Hana Hikoyabi as the Head of Bapeda Kab. Jayapura and Origenes Monim as the Principal of Customary School in Hobong Sentani. Their support and energy motivate the researcher to go beyond her capability.

\section{REFERENCES}

Bunanta, M. (2012). Anak Perlu Buku Baik. Diunduh dari 
Laman:www.perspektifbaru.com/ wawancara/857.

Crippen, M. (2012). The Value of Children's Literature. Oneota Reading Journal. Spring. www.luther.edu.

Chiparausha, B. and Frereick M. (2018). The Role of Folktales in the Preservation of Indigenous Knowledge Among the Shona: A Review Based on Aaron C. Hodza's Ngano Dzamatambidzanwa. Southern African Journal for Folklore Studies. 24 (2), 207-219.

Danandjaja, J. (2002). Folklor Indonesia: Ilmu Gosip, Dongeng, dan lain-lain. Jakarta: Pustaka Utama Grafiti.

Deda, A. (2018). Kamus Trilingual: Sentani - Indonesia - English. Yogyakarta: Penerbit Kepel.

Dundes, A. (ed). (1984). Sacred Narrative: Readings in the Theory of Myth. Berkeley: University of California Press.

Hartzler, M. (1992). A Brief Phonology of the Sentani, Afeuyear III no. 4. Jayapura: Percetakan Universitas Cenderawasih.

Hastuti, E., Reza C., and Teddy O. (2017). Minang Language Learning Through Folklore. Man in India. 97 (24), 469-476.

Kementrian Pendidikan Nasional. (2011). Panduan Pelaksanaan Pendidikan Karakter. Jakarta: Kementrian Pendidikan Nasional.

Kristanto, M. (2014). Pemanfaatan Cerita Rakyat sebagai Penanaman Etika untuk Membentuk Pendidikan Karakter Bangsa. Mimbar Sekolah Dasar. 1 (1), 59-64.

Lazar, G. (2002). Literature and Language

Teaching: A Guide for Teachers and Trainers. Cambridge: Cambridge University Press.
Lwin, SM. (2016). Using Folktales for Language Teaching. The English Teacher. 44 (2), 74-83.

Masoni, L. (2018). Folk Narrative and EFL: A Narrative Approach to Language Learning. Journal of Literature and Art Studies. 8 (4) 111117.

Normawati. (2014). Penentuan Cerita Rakyat Sentani Jayapura Kasuari dan Burung Pipit sebagai Bahan Bacaan Siswa SD. Jurnal Metasastra. 7(2), 201-214.

Poley, J. (1978). American Folklore and Legend. New York: The Reader's Digest Association, Inc.

Prasetyo, A. (2016). Folklore in EFL: The Local Wisdom Implementation of Indonesian Curriculum. Journal of ELT Research. 1 (2), 194-199.

Rahayu, K.(2010). Arti Penting Folklore dan Traditional Knowledge bagi Indonesia sebagai 'The County of Origin'. https://www.neliti.com/ id/ publication/241671.

Ratna, N.K. (2014). Peranan Karya Sastra, Seni dan Budaya dalam Pendidikan Karakter. Yogyakarta: Pustaka Pelajar.

Setyawan, A., Sarwiji S., \& Slamet (2017). Character Education Values in Pacitan Folklore. Komposisi: Jurnal Pendidikan, Bahasa, Sastra dan Seni. 18 (1), 91-106. DOI: https://doi. org/10.24036/komposisi.v18i1. 7925 .

Yektiningtyas, M. \& Monika G.(2017). Pemertahanan Bahasa Sentani untuk Anak dengan Menggunakan Cerita Rakyat, Kabupaten Jayapura, Papua. Laporan Penelitian PDUPT DIKTI 2017. 